\title{
Some reflections on the teaching of color sketch in art design
}

\author{
Cui $X u^{1, a}$ \\ ${ }^{1}$ Changchun institute of technology, visual arts, Jilin 130000, China \\ a xucuixucui@126.com
}

\begin{abstract}
Key words: Art and design, color sketch, eaching practice
\end{abstract}
\begin{abstract}
After years of teaching practice, aiming at the existing problems in the teaching of color sketch reviews and finishing, color painting course is one of the compulsory basic course of art design specialty in universities, plays a bridge role in teaching and learning this course will directly affect students' learning of the following courses. But there are many problems in the current color sketch teaching in University, to reposition on this course problems the author appeared through the collation of College color sketch teaching, purpose is very clear: To explore in the current college color sketch teaching process problems and solutions, to make the color sketch curriculum and art design specialized curriculum closely, so as to achieve better teaching effect.
\end{abstract}

\section{Introduction}

The Tang Dynasty painter Zhang Zao's "nature outside, in the heart of the theory of artistic creation", the artist is required in the process of artistic creation, to give full play to the subjective creative thinking, their keen observation and subjective expression, have this ability is very necessary for the designer or artist, is a computer and other tools can not replace. Therefore, it is necessary to have these abilities for the students who study art design. In China, overall, the current art design professional teaching color sketch has attracted a lot of attention of education, and achieved certain results, but still uneven in quality, there are many problems to be solved in the process of teaching, the author summed up the main problems are as follows.

\section{The existence of color teaching in Colleges and Universities}

In the teaching of color sketch course in Colleges and universities, the teaching system of Western painting is still in use. Many of the current domestic art design professional color course teaching is basically the use of Western painting color teaching system, the teaching idea is wrong. In the first half of the twentieth Century, educators have realized the art design specialty and pure painting professional have the essential difference, under the guidance of this concept, they think the color sketch teaching in art design college should stop using the teaching mode of painting color sketch, some new ideas of teaching color painting came into being, but realistic painting the concept of color view soon banned it. After the reform and opening up, the design of professional color sketch teaching mode has changed, but the change is not obvious. In the second half of the twentieth Century, educators to further realize that art design is the integration of art and technology, to reflect the practical value, aesthetic value, science and aesthetics, in order to cultivate such talents, colleges and universities for color sketch teaching of art and design was carried out by the system of teaching painting teaching to design color system change the bold reform as a starting point from the characteristics of professional art and design professional, clear color sketch teaching objectives; developed a color sketch of practical scheme; put forward new design color sketch, after summary and practice has made some achievements, the teaching system has been improved. In this teaching system can not only train the students' ability to use, color perception, and the students' design awareness and innovative thinking ability has been trained and improved, after such training, students have the learning ability of art design, the new teaching system is in line with the characteristics of the subject design subjects.

In the course of the teaching of color sketch, teachers generally do not pay much attention to the 
teaching process. With the recent national art students enrollment, college art students more, comprehensive quality and drawing students' basic skills are relatively weak, communication between teachers and students and lead to less teachers do not understand the students, teachers and students unfamiliar, the teaching process of the teachers without passion, students lack of learning enthusiasm. For example, in some domestic university art design professional color sketch teaching, teachers for some more work, students are required to take photos, and even asked the students to use computer software for photo processing, and control of color painting computer processed photograph, students use this method to draw a picture of the lack of anger, not smart and because the students in the drawing process. There is no choice for photo copying, and did not join the subjective ideas, the students are passive, students' learning initiative is not, the subjective feelings of students in the picture is also "copy" to replace, the enthusiasm of students, students to master the knowledge of color as can be imagined. In the training of students under the teaching idea is simple, their subjective use of color, the subjective aesthetic ability can not exercise, which seriously affected the subsequent course of study for students. The author thinks that the process of color sketch should be the subjective creation process, the experience process and the enjoyment of the painting. We should give full play to the initiative of students of color sketch teaching, should guide students in the creation of the feelings and understanding in the creation of the object, or even have a certain emotional communication in the process of creation, to the subjective use of color. At this point, the design of college teachers should clear teaching contents in the teaching process, emphasizes the diversity of knowledge, the teachers should let the students on the scene of things, people through the sketch, the sketch of the process, according to the different requirements of color sketch training subject, training students keen observation use and choice of treatment, subjective ability and color training students' ability to actively mobilize the initiative of students, so that students can master the knowledge of color, as in the future and lay a solid foundation of art design.

The teaching content is not in harmony with the major of the students. Generally speaking, College of art and design professional color painting course teaching is a "broad brush" approach, do not consider the major differences in the teaching, the teaching ideas, teaching methods, the same are using the same teaching content is absolutely not desirable. Sketch course teaching should be closely combined with professional characteristics to set. College of art design professional is usually divided into the environment art design, graphic design, visual communication design, 3D dynamic imaging specialty, the author believes that the different professional color sketch teaching should be in focus, such as color painting teaching of environmental art and design professional should side description in the construction aspect, color sketch teaching of plane advertisement the design of professional color design should focus on learning, training application ability pay attention to the color of the professional characteristics itself can also make some text training, at the same time that picture should be on a plane structure, give students some painting thoughts and diary timely, teachers should communicate with students; vision in communication major color sketch teaching process and pay attention to color collocation and point, line, form relations training , this will achieve a satisfactory teaching effect, will allow students to benefit from life.

\section{Summary}

According to the existed problems in the teaching of color sketch paper finishing, color painting should not only exercise their powers of observation and expression, but also to improve the ability to use color based on the students' aesthetic consciousness, emotion experience and design consciousness, students have the ability is the basis of art curriculum, the author aimed at these problems put forward the corresponding countermeasures, hope that the author's opinion, it can provide a way for art design professional color sketch teaching. 


\section{References}

[1] YeMa, Yongbo Chou, "color foundation", Liaoning Fine Arts Publishing House, 2005.

[2] Jin yang, Wen "painting", Shandong people's publishing house, 1983.

[3]Yiping Ma, "color", Southwestern Normal University press, 2000.

[4]Qinguo Zhao, "color form language", Shandong Fine Arts Publishing House, 2002.

[5] Gang Zhou, "experience design and color", Hangzhou: The China Academy of Art press, 2004.

[6] XixuHong, "sketch and color, an endless topic", appeared in the "Suzhou arts and crafts occupation.Journal of the College of art, 2003. 